\title{
The Opportunity Economy: Enduring Lessons from the Rise and Fall of the New Economy
}

\author{
Michael Alles. Rutgers Business School. USA.
}

Anthony Alles. CEO, Tahoe Networks. USA.

\begin{abstract}
In this paper we argue that the business model underlying the new economy is based on the following interrelated and self-reinforcing forces:

1. The development of a new strategy of opportunity, which focuses on the use of creative innovation to open up new market spaces, rather than using exploitive innovation to prolong the life of existing products.

2. The democratization of competition thanks to the Internet and to process outsourcing.

3. Taken together, these forces result in a profound shift in the source of value creation in firms from processes and physical assets to people.

With the drivers of business success so fundamentally transformed, almost all aspects of the firm and its management also need to change, from valuation, resource allocation and worker compensation, to what it takes to retain workers and promote innovation. But while the rules of business have changed, there has not been a corresponding shift in awareness among most managers. Assuming that there is nothing new in the New Economy is a profound and dangerous mistake. Managers that are so short sighted will find that they have not only lost out on the opportunities that the new economy continues to provide, but that the market downturn has only deferred, rather than eliminated, the threats that change poses to their firms.
\end{abstract}

Key words: new economy, strategy, Internet, creative and exploitive innovation.

\section{LAST RITES FOR THE NEW ECONOMY?}

Just a few years ago, an article on the New Economy such as this would have started with a breathless description about the massive amounts of wealth that it had created. Today, it is equally impossible to avoid mentioning the stunning 
market losses since the dotcom meltdown of the summer of 2000. It turns out that the long stock market boom was nothing compared to the fastest and greatest "correction" in history.

A statement by Mike Moore (2000, page 43) of "Crossing the Chasm" fame best expressed the prevailing sentiment in those halcyon days: "Stock price is the foundation of the New Economy." When that was written it was not only meant to herald the birth of the new economy but also to be a self-congratulatory cry of triumph for the age of NASDAQ, IPOs and day traders. With most of the Internet firms lauded at the time now bankrupt, Moore's comment today has the ring of an epitaph. Dotcom has become a word to be shunned, as investors flock back to established old economy firms - the same "notcoms" once widely dismissed as dinosaurs doomed to extinction from "new, new thing" startups. ${ }^{1}$

The problem with having used stock price as the metric of success for new economy firms is that when the price fell the obvious conclusion drawn was that there was really nothing of substance there in the first place. Given the trillions of dollars that investors have lost it is not surprising that there is now a sense of caution about new economy firms. But there is also the danger that the backlash against "irrational exuberance" will be an equally misguided belief that there is really nothing new in the new economy. ${ }^{2}$

No less a figure than Michael Porter (2001) recently pronounced that: "I believe that the experiences companies have had with the internet thus far must be largely discounted and that many of the lessons learned must be forgottenE even the phrases "new economy" and "old economy" are rapidly losing their relevance, if they ever had any." There is undoubtedly a virtue in scaling back expectations about the possibilities for firm success and reemphasizing the need for profitability and a workable strategy. But what is overlooked in the "told you so" arguments heard so often lately is that the key change brought about by the new economy is not in how firms use strategy to translate potential value into profits, but in how that value is created in the first place.

We argue in this paper that assuming that there is nothing new in the new economy is a profound and dangerous mistake. Firms that are so short sighted will find they have not only lost out on the opportunities that this economy provides, but that the market correction has only deferred, rather than eliminated, the threats that change poses to them. The fact is that there really is something unique about

\footnotetext{
${ }^{1}$ See for example, Lewis (1999), Hamel (1999) and Sahlman (1999)—or any issue, up to May 2000, of Fast Company, Industry Standard, or Business 2.0.
}

${ }^{2}$ Shiller (2000). 
the drivers of the new economy, and they will continue to radically transform businesses in the $21^{\text {st }}$ century.

Despite the corrections to an overheated market for technology firms, the one word that captures the new economy is opportunity. The new economy consists of firms pursuing a novel strategy of seeking opportunities to create new markets, using the creative talent of their people. At least until the recent round of layoffs, it was fashionable for firms to talk of recognizing that people are their number one resource. But that was more a reaction to tight labor markets than to a true understanding of the profound shifts that have taken place in what firms do and how they do it. What we show in this article is that the new economy consists of a set of forces whose most important effect is to shift the source of value creation in firms from assets and processes to people. And when that happens, the key variable that managers have to focus on is the opportunity cost of their employees' time.

Leading Silicon Valley firms, led by innovators like Cisco Systems, have started to internalize the implications of being in an Opportunity Economy by the development of such innovative management tools as the "spin-in". But most other firms have yet to fully recognize how much the rules of the game have changed from the old economy to the new. With the market correction reducing the immediate threat of competition from startups, many established firms will inevitably conclude that they have less reason to change. Some may even feel vindicated for sticking with "tried and true" ways and indeed, when the recession came, many firms abandoned their new found appreciation of their employees in favor of cost cutting.

In this paper we counter the backlash against the irrational exuberance that accompanied the rise of the new economy by identifying what was truly new and lasting about it. Ironically the economic downturn increases the value of our analysis for managers of established firms, for the demise of many of their startup competitors gives them a second chance to adopt the policies that will enable them to succeed in the new economy. But first managers of both established and startup firms have to understand that their concept of how firm's create value has been fundamentally transformed.

We begin our discussion of the strategy of opportunity that underlies the new economy in section 2 of the paper. We then introduce the building blocks of our new business model, with creative and exploitive innovations discussed in section 3 and process outsourcing in section 4 , which, together, result in the fundamental shift in the source of value creation from assets and processes to people, as we argue in section 5. Section 6 then examines the implications of the new business model for firm valuation, human resources policies and management control systems. Section 7 offers concluding comments. 


\section{A STRATEGY OF SEIZING OPPORTUNITIES}

The most obvious characterization of the new economy is that it is all about technology. From a longer perspective, though, technological advances have been taking place regularly over the last two centuries, sometimes more rapidly and profoundly than today. What is different now is that the technology that virtually defines the new economy, the Internet, is an innovation unlike any that has preceded it. The distinctive characteristic of the Internet is that it is a great leveler: the startup costs for having a significance presence on the web are low, both in absolute terms and relative to the potential value creation. ${ }^{3}$ The lower entry costs mean that in cyberspace everyone can potentially look equally attractive and credible and have equal access to all customers everywhere, with the latest entrant having a presence as significant as the oldest and largest firm. Distance, size, history, none of these matters. ${ }^{4}$

It is this egalitarian aspect that makes the Internet unique as far as the impact of technology on business is concerned. Prior technological advances, such as electricity, automobiles and the telephone also had a large effect on industry. ${ }^{5}$ But apart from for the firms directly involved in their manufacture, for most businesses these advances were only a means of more easily doing what they were already doing. In other words, they only addressed how firms did things, not what they did or why. The Internet is different because it is not just a technological tool, but also an arena for competition, and so fundamentally alters not just a firm's production function but also its strategic environment. ${ }^{6}$

With the collapse of e-commerce, in particular, there has been a shift towards seeing the major impact of the Internet as improving the efficiency of existing large firms. ${ }^{7}$ While the benefits of the Internet as an internal control and communication device cannot be underestimated, it is premature to dismiss the Internet as simply a means of cost reduction. Doing business on the Internet has effects beyond simply saving money - it fundamentally shapes firm culture and strategy.

\footnotetext{
${ }^{3}$ For example, GE spent only $\$ 15,000$ on the auction software for its internal B2B site. Cisco spent $\$ 50$ million upfront for its Cisco Online site and plans to spend ten million annually on upkeep-but the cost savings are over \$530 million each and every year (Vasarhelyi, 2000).

${ }^{4}$ See "Tricks of the Trade: New tool can make even a small web site look bold, big and beautiful”, Newsweek (E-Life Special Issue, pp. 53-56, July 2000).

${ }^{5}$ Gordon (2000).

${ }^{6}$ An excellent summary of these characteristics of the Internet is provided in the special report on E-Management in the November $11^{\text {th }}, 2000$ issue of the Economist.

${ }^{7}$ Porter (2001). See also “New Economy: Old-School Rigor”, New York Times (June 12 $\left.2^{\text {th }}, 2000\right)$.
} 
For decades, firm strategy consisted of leveraging a core competency in cost or quality. But differentiating on these dimensions are essentially ways of competing in an existing market where established competitors seek to stand out from each other. By contrast, the essence of the new economy is the creation of new markets through the seizing of opportunities and the development of innovative products and services that have not existed before. ${ }^{8}$

Of course, there have always been new product introductions. But what is special about this economy is that innovation has become not just a means of supporting an existing strategy, but a strategy in its own right. Technology has reached a critical stage at which it can create demand rather than responding to existing needs. ${ }^{9}$ Innovation also creates opportunities for complementary or next generation product, thus allowing the strategy to feed on and sustain itself. For example, the development of Internet based e-commerce spawned the creation of whole industries in e-commerce consulting, marketing, site development and the "electronization" of firms in general. Most important of all, the Internet is leading to the rise of networks as the dominant paradigm for both competition and organizational architecture. This stimulates whole new areas for innovation, from the enablers of the networks - the related hardware, software, communication tools and the integration of it all - to the opportunities this will provide for new products, services and markets. ${ }^{10}$ Of course, it is inevitable that many ideas, perhaps even the best ones, will fall by the wayside. But that is the process of creative destruction that drives capitalism, not an indication that opportunities are lacking or that innovation is dying out, as some seem to have concluded lately.

The openness of investors to the potential of small firms and the desire for established firms to keep pace with innovation also leads firms in the new economy

\footnotetext{
${ }^{8}$ For example, in EMC Corporation up to $80 \%$ of annual revenues comes from products introduced that same year (Austin, Nolan and Cotteleer, 2001; Hemp, 2001). The special issue of Journal of Management Information Systems (2000), Vol. 16, n.4, discusses the impact of information technology investment on organizational performance.

${ }^{9}$ For example, consider the GPS satellite system. While it has been in place for twenty years, only in the last few years has it had a major impact on the non-defense sector. In the future it may well spawn a whole host of new industries, from an air-traffic control system independent of ground controllers to order tracking for supply chain management as well as consumer products for hikers, golfers and drivers. See "Satellites Guiding Industries on the Move”, New York Times, September 28, 1998: "Thousands of American companies are putting global positioning satellite data to work for such commercial purposes as mapping delivery routes, tracking products from factory to retail shelf and monitoring whereabouts of mobile workers; many businesses now consider GPS technology a utility like the Internet; Commerce Department estimates worldwide GPS equipment sales will reach \$4 billion this year and \$16 billion by 2003 "
}

${ }^{10}$ Tapscott, Ticoll and Lowy (2000), Suarez-Villa (1998). 
to have a strategy option that never existed before: create companies in the expectation that they will be acquired. While few VC firms will say that they invest in a startup "built to flip," the fact remains that in some industriesespecially in networking, thanks to the lead of Cisco Systems-being acquired is a perfectly desirable exit strategy. ${ }^{11}$ Clearly the tactics of managers in such a firm is going to be different from that of someone who plans to build a company that will grow and last for generations, like the family companies of the old economy. Such opportunistic startups are often led by that phenomenon of the new economy, the serial entrepreneur. Essentially firms such as these are following a strategy of outsourcing innovation for established companies, and as such, their real customers are potential acquirers, not end consumers. In many ways, we would argue that the market acceptance of the build to acquire strategy has been essential to the growth of the new economy. It allows entrepreneurs to specialize on only the startup phase of a business as opposed to having to also develop and demonstrate the quite different skills needed to run a larger company (hence, the emergence of the new field of entrepreneurship in business schools). It also allows startups to obtain funding at the idea stage, deferring planning for growing the company.

\section{PUTTING THE OPPORTUNITY STRATEGY INTO PRACTICE: CREATIVE AND EXPLOITIVE INNOVATION}

What does a firm have to do to compete on the basis of innovation? It has to have a process for the generation of innovation, since with rapid changes in technology, no one innovation, however revolutionary, can by itself be the basis for a successful firm. In other words, a strategy of opportunity and innovation is dynamic and offensive in nature, not stationary and defensive. It is a process of creative destruction, with a stream of new innovations building on, but also supplanting the old. ${ }^{12}$ To implement such a strategy what the firm has to do is to appreciate what kind of innovation the new economy is looking for and find ways of achieving it in a systematic fashion.

While innovation has been classified is a myriad of ways for different purposes (disruptive and sustaining, product versus process and so on) to appreciate why the new economy is driven so much by startups we must understand how innovation

\footnotetext{
${ }^{11}$ Wheelwright et al (2000). See also the special issue of Fast Company: Built to Flip? (March 2000).

${ }^{12}$ For example, EMC had so much faith in the possibilities of mainframe data storage devices, that almost a soon as that technology become available it shut down production of memory boards, even though that business accounted for $80 \%$ of its revenues at that time (Hemp, 2001).
} 
serves as the nexus between the firm's resources and its strategy, between how and why it does what it does. And for that purpose we introduce the distinction between creative and exploitive innovation. The difference between these two types of innovation in many ways defines the difference between the new and old economies.

The purpose of exploitive innovation is to support and make the most of an already existing product space, perhaps expanding that space, but not creating a new one. It is based on incremental improvement to the base technology or marketing strategy that underlies a firm's existing products. Such innovation need not be pursued only by the firm making the existing products - other firms may leverage the existence of the product line, in the way that there are many vendors of Windows ${ }^{\mathrm{a}}$ compatible software-but clearly the incumbent is favored in this environment.

Given that exploitive innovations are complementary to existing products, they are likely to more rapidly become commodities sold on the basis of their cost and quality. ${ }^{13}$ Not only must exploitive innovations then be produced cheaply, but also they must be made backward compatible with the existing product line. Further, there must be a clear migration path for consumers from the old to the new technology and this path must be communicated to them. In other words, competing using incrementally improving mature technology requires the careful management of all the processes of a firm, since it is not the idea that counts as much in this strategy as the entire value chain that delivers the product to its customer base in a cost effective manner.

The imperative in the new economy, however, is being first to market, and what is essential for a strategy of being the latest and newest is innovation that opens up the competitive environment. A startup can only claim a high market valuation if it is perceived as having carved a distinct market space for itself, and this requires more than exploitive innovation. It is harder to avoid being perceived as a niche player when your products are only complementary to those of established firms, and it is more difficult to credibly compete on cost and quality against the primary industry players who are larger and more experienced. What new economy firms seek are not exploitive innovations, but creative innovations, which are ones that permit the inception of a new product space, not just a refinement of an existing one. They are not just technologies, but associated marketing and strategy breakthroughs, which, in contrast to exploitive innovations,

\footnotetext{
${ }^{13}$ To the extent that the product has to fit in with existing customers' expectations and needs, anything other than incremental improvement is a drawback—consider the consumer backlash that Ford experienced with its "rounded" Taurus, or Coca Cola with its infamous New Coke.
} 
represent a distinct step up in capability or performance, and —most important of all-are perceived as such by customers.

Since markets are continuously in a state of flux in the new economy and there is no need to fit into an established path, as with exploitive innovation, entrepreneurs have greater ability to shape the potential of their creative innovation. They can market their product as disruptive to existing products and relationships. Unlike with exploitive innovations, the product and marketing path is not constrained by the needs of existing customers, products and strategies. Hence, by flexibly pursuing and seizing opportunities, entrepreneurs can take a basically exploitive innovation and make it a creative one, with disruptive effects on existing customer and product relationships.

The strategy of seeking and seizing the opportunity to create a market through the use of creative innovation is a virtually defining aspect of the new economy. While the dynamic nature of strategy today has received a great deal of attention in the business media less thought has been given to how this strategy can be feasibly implemented, or to how the innovation comes about in the first place. ${ }^{14}$

\section{OUTSOURCING: DEMOCRATIZING COMPETITION}

The basis of all technology-enabled firms in the new economy is the Internet, and as we have argued, the unique aspect of the Internet is its leveling effect. The consequence of this effect is to both create new product spaces and make the ones of established player much more vulnerable to attack through the use of a clever creative innovation. The first and most famous example of this phenomenon is still the best, of how in the book selling business a century long strategy of consolidation by Barnes and Noble to become the country's largest bookseller was rendered worthless virtually overnight by Jeff Bezos's insight that books were the ideal product for e-commerce. The pervasiveness of the Internet, and creative use of its capabilities, such as reader reviews and search capabilities, allowed Amazon to completely overwhelm Barnes and Noble's incumbency advantage, with a fraction of its resources and none of its experience. ${ }^{15}$

However, just having that creative idea would not have guaranteed success for Amazon.com. Not so long ago, a challenger to Barnes and Noble could not

\footnotetext{
${ }^{14}$ Contrast our classification of innovation into those that are exploitive and creative with the concept of "Disruptive Innovations" and "Sustaining Innovations" popularized by Clayton Christensen (Christensen, 1997). More analysis of this issue is provided by Alles (2001). Leifer et al (2000) provides yet another categorization of innovation and the way that firms can foster it.
}

${ }^{15}$ Ghemawat and Baird (2000). 
have credibly competed with it without replicating its physical assets-its hundreds of stores and warehouses. At its inception, though, Amazon could not have afforded to build a single facility as impressive as any local Barnes and Noble superstore, which would have doomed it if the way to attract customers was by providing comparable "bricks and mortar" storefronts, or the warehouses that comprise a bookstores back office.

Just because a startup can cheaply create a website that is as attractive as that of an older and larger firm, does not mean that it can successfully compete against it in the long run. The goods still have to be built and delivered. This is where the second great force in the new economy enters: the ability to outsource virtually all business processes. This is not true in all places and for all types of startups, but it is a distinguishing feature of Silicon Valley and increasingly so in such Silicon Valley "wannabes" as Austin, Texas and Silicon Alley in New York. In these centers of innovation, the infrastructure exists for startups to outsource almost all the activities and functions necessary to develop a going concern, from administration and human resource management to manufacturing. Federal Express and UPS take over delivery with unparalleled order tracking capabilities. Venture capital firms offer not just financing but management support and oversight, with experienced managers on retainer to fill the needs of their clients. ASPs and "technology on tap" providers allow firms to "externalize" their business software needs-which in this information age, means almost all of their business processes-while OEMs take over the manufacturing function. With all parties integrated through Supply Chain Management, the ability exists today to create a "virtual corporation" with even a "virtual CEO". ${ }^{16}$

One outcome of outsourcing processes rather than developing them internally is the substitution of a variable cost for an upfront fixed cost. Per-unit cost of outsourcing may be higher than for an internally run process but that consideration only matters if the strategy of the firm is to compete on cost. For most high-tech startups, though, the strategic imperative is to get to market first and to compete by offering innovative features not available elsewhere. Hence cost is a secondary concern and more than offset by a major benefit of outsourcing, almost infinite scalability. That allows even a new startup to have the credibility of an established firm. ${ }^{17}$

\footnotetext{
${ }^{16}$ Cross (1995), Lacity, Willcocks and Feeny (1995), Roberts and Tempest (1999). See also "Ignore the Label, It's Flextronics Inside: Outsourcing's New Cachet in Silicon Valley", New York Times (February 15, 2001) and "Technology on Tap", Business Week (June 19 $9^{\text {th }}, 2000$, pp. 74-87).

${ }^{17}$ See "Building to Scale”, Newsweek (E-Life Special Issue, pp. 45-52, July 2000).
} 
Outsourcing is just one example of a fundamental shift in how firms carry out their business. It is a natural extension of the idea from the 1980's that each firm needs to develop and focus on its core competencies. ${ }^{18}$ All else is "context" and while execution of that context is essential for the generation of profits, it cannot draw scarce management attention away from the primary focus on the firms' core functions. Moreover, the insight that business has gained recently is that while a function may be context for it, it is the core competence of another, more specialized firm. Thus by outsourcing a firm can obtain best practice performance in all functions, core and context, leveraging an innovation into a marketable product. ${ }^{19}$ Eventually relationships across firms will grow and deepen until there is created what Tapscott, Ticoll and Lowy (2000) call B-webs: "internetworked, fluid-sometimes highly structured, sometimes amorphous-sets of contributors [that] come together to create value for customers and wealth for their shareholders. In the most elegant of b-webs, each participant focuses on a limited set of core competencies, the things that it does best." ${ }^{20}$

In particular, the key core competency that startups need to focus on in the new economy is their ability to innovate. Indeed, in many cases, that is all that they can do well, considering the age and experience of the entrepreneurs. Such limitations would have doomed an old economy firm where translating the innovation into a full value chain was more important than the idea itself. In that environment, a startup would not even have been able to raise funding in the first place without the assurance that it could itself perform all the activities needed to run a large firm-obviously something of a Catch-22 hurdle for an entrepreneur. What aspects of a business should be outsourced and which processes should be retained internally to develop the firm's core competency remains open issues, but there is no doubt that outsourcing is one of the most powerful tools ever developed to help entrepreneurs take on and defeat larger and older competitors.

Of course, the market meltdown has led some people to abandon their faith in outsourcing as with much else in the new economy. ${ }^{21}$ It has been pointed out that outsourcing is not as cheap as it first appeared, when, for instance, suppliers would take payment in stock options. But the main effect of outsourcing is not in cutting costs, but in giving firms something far more valuable in today's economy: speed, credibility and flexibility. And as far as cost is concerned, it is true that it turned out that dotcoms had to spend many millions more than anticipated to purchase

\footnotetext{
${ }^{18}$ Prahalad and Hamel (1990).

${ }^{19}$ Moore (2000).

${ }^{20}$ See also Moore (1993).

${ }^{21}$ Young and Macneil (1999).
} 
infrastructure. But such costs still pale into insignificance when compared to the capital costs considered routine in old economy firms. For example, in the late 1990's Gillette spent nearly one billion dollars in developing its Mach 3 razor blade..$^{22}$ Imagine what could have been done with such an amount of money in Silicon Valley during that same time period.

\section{FROM ASSETS AND PROCESSES TO PEOPLE}

Taken together, the leveling effect of the Internet and process outsourcing underpinned the tremendous success of startup firms in the new economy. They could credibly seek financing to compete head to head with larger and older firms, without being intimidated by their incumbency advantages. It is particularly striking to compare the virtual structure of the new economy firm with what was considered, only a few short years ago, to be essential for a firm's success: the physical resources and assets that it owns and the processes in place for using them. Michael Porter (1996, page 62), the dean of strategy for old economy firms, argued that the source of competitive advantage for firms is how effectively they perform "the hundreds of activities required to create, produce, sell, and deliver their products and services, such as calling on customers, assembling final products, and training employees." The popularity of such techniques as Business Process Reengineering, Activity Based Management and Best Practice Benchmarking in the 1990's illustrates the importance in old economy firms of controlling processes in order to be able to cost effectively produce high quality output. An emphasis on processes and assets clearly favors larger and more established firms. The necessity to perform internal activities with great efficiency reflects the greater likelihood that old economy firms compete on the provision of high quality products or services at the lowest possible cost. In other words, these firms produce commodity like items that they have to differentiate in some fashion from the output of their competitors.

Most new economy firms, however, are attempting to be the first to market with a creative innovation and cost and quality are of secondary concern. This is true of even such large, established new economy firms as Microsoft or Cisco, whose products are considered largely unique. Few high-end servers for instance, are bought purely on the basis of cost, while issues such as compatibility dominate software purchase decisions. Optimizing processes is of secondary importance in this strategic environment, compared to the management of the human resources that give rise to innovation.

\footnotetext{
${ }^{22}$ BusinessWeek (February $\left.1^{\text {st }}, 1999\right)$.
} 
Consequently, the fundamental effect of adopting a strategy of opportunity, of having low barriers to entry and the ability to outsource in the new economy is to shift the source of value generation in firms from assets and processes to people, from physical to human capital. ${ }^{23}$ It has been frequently demonstrated in the digital economy that a few talented people can develop and execute a business that completely transforms an industry and overturns existing competitors, or develop a vastly lucrative market that never existed before. That is almost the mythical view of the startup, as evidenced by the success of such firms as Amazon.com, Cisco, Priceline.com and Yahoo. These are not isolated examples, however, but reflections of a new reality in the way that businesses compete.

By contrast, in the old economy in which assets and processes in place were the means of competition, the role of the worker was very different. When managing processes, firms aim for control and stability through standardization and the elimination of uncertainty. The assumption is that that there is one optimal way of processing inputs into outputs and the object is to work towards attaining that ideal. In this environment human variability results in inconsistency, and is to be compensated for, not celebrated. Hence processes are carefully constructed to allow the company to act independently of its workers since reliability and cost effectiveness cannot be achieved if the process is dependent upon the particular workers available at any given time. As Christensen and Overdorf (2000, page 71) state: "at highly successful firms, like McKinsey \& Company, the processes and values have become so powerful that it almost doesn't matter which people get assigned to which project teams. Hundreds of MBAs join the firm every year, and almost as many leave. But the firm is able to crank out high-quality work year after year because its core capabilities are rooted in processes and values rather that in its [human] resources." This is the embodiment of a strategy driven emphasis on process over people. ${ }^{24}$

To illustrate the difference in the role of people and processes between the old economy and the new, consider a classic old economy firm like General Motors. It obviously has many talented engineers, but over many decades few have left to found or join startups. One reason is that it is almost absurd to suggest such a thing as a startup in the automobile industry. The initial cost to be even a supplier to that industry, let alone to be a full-fledged auto manufacturer, is exceedingly

\footnotetext{
${ }^{23}$ Benson (1999) examines the effect of outsourcing on the flexibility and productivity of workers. Shane (2001) discusses the forces leading to the creation of technology firms.

${ }^{24}$ The ultimate example of the supremacy of assets over people in the old economy took place at the end of the Second World War. In compensation for the destruction of its industrial base, Russia dismantled and shipped back home thousands of factories from the defeated Germany. Clearly the plants and equipment were considered the critical part of the production process, not the people who operated them.
} 
high. Indeed, there have been virtually no new car manufacturers created anywhere in the world in the last few decades. Having an idea for a better car is simply not enough to be viable as a startup: Cars are essentially a commodity item within their particular market niche and the processes that existing automobile manufactures have set up to wring out excess costs while achieving high quality would be very difficult, costly and time consuming for an entrant to replicate.

It is instructive that when employees of old economy firms do leave, their most common new job is that of consultant-in other words, they continue to act as virtual employees of their old firms and their job is to try and improve those firms, rather than supplant them. The way in which workers are of value in the old economy is by being complementary to the physical assets and processes in place at the established companies.

Startups, on the other hand, would cease to exist in the absence of their key founders and staff. More to the point, their strategies preclude an emphasis on processes at the expense of people, because flexibility is key to their success. Unlike physical assets and processes that are designed to do one thing very well, people are more flexible and capable of innovation. ${ }^{25}$ The most important flexibility that talented workers demonstrate is the ability to take an exploitive innovation and make it creative. Such a capability to be flexible is especially valuable when combined with the first aspect of the new economy, that it is relatively easier now to translate ideas into an operational business.

In short, a key difference between old and new economy firms is that the source of value in startups is the talent and creativity of its workers and that the constraints on rapidly and credibly implementing the business plan are lowered relative to old economy standards. The importance of workers over processes or assets in the new economy was demonstrated by the amounts that firms like Cisco were willing to pay for small startups that consisted mainly of the former and possessed little of the latter. What Cisco was really buying in these acquisitions was a pre-assembled "gene pool" of scarce workers. ${ }^{26}$ The premium that Cisco paid for its acquisitions was a reflection of the opportunity cost of workers' time: they needed to be given a reason to work on this project in this firm, rather than in one of the many alternatives then open to them. This opportunity cost is clearly higher in areas dense with alternatives, which can be geographic areas like Silicon Valley, or functional areas where talent is scarce, such as in networking. While the opportunity cost may have fallen during the current downturn, the general

\footnotetext{
${ }^{25}$ See Upton (1995), and in particular, MacCormack, Verganti and Iansiti (2001).

${ }^{26}$ Wheelwright et al (2001). See also Bunnell (2000).
} 
principle remains that today it is the ability of workers to drive innovation that determines firm success.

A reflection of this fact is the development over the last few years of the new field of knowledge management. ${ }^{27}$ But while it is a clear strategic necessity for firms to try and separate knowledge from the workers that possess it as way of leveraging and preserving it, ultimately the issue is how that store of knowledge is used and transformed into creative innovation.

\section{MANAGING A FIRM IN THE OPPORTUNITY ECONOMY}

The forces that shape the new economy-an opportunistic strategy of seeking new markets by the use of creative innovation, outsourcing context and the shift from asset to people - are essential for each other and reinforce each other's effects. Thus a strategy of being first to market cannot exist if there is no space for creative innovation to take root. Startups cannot focus on creative innovation if they cannot outsource context. Outsourcing, SCM and the development of B-webs open up fresh strategic opportunities for firms to service the needs of the new economy, so feeding a strategy of competing by innovation. ${ }^{28}$

Few firms, though, can be confident that they have fully internalized all these forces. Established firms, in particular, face an acute problem in that their need to change to a strategy of opportunity is much more urgent than their ability to bring about the internal changes needed to support such a strategy. They have to go through the uncertain and expensive process of change management to align their existing processes and people to the new strategy, while a startup that can follow a clean sheet approach. With their culture revolving around the use of assets and processes to achieve exploitive innovation, it is much harder for established firms to put in place the cultures and control systems that focus on creative innovation and the people who bring it about.

What all firms, either new or established, have to aim for is consistency across the fundamental forces that shape the new economy. In particular, how they do things has to match what they want to do and why they do it. In this respect, the most profound change represented by the new economy is in the shift in value creation from processes to people. It is the failure to internalize the full implications

\footnotetext{
${ }^{27}$ Hansen, Nohria and Tierney (1999). See also the special issue on knowledge management in Journal of Management Information Systems, (2000) Vol.18, n.1.

${ }^{28}$ Tapscott, Ticoll and Lowy (2000).
} 
of this fundamental paradigm shift that creates the greatest difficulties for managers implementing the new economy business model. ${ }^{29}$

\subsection{Rethinking Worker Valuation: Real Options}

The fact that the value generating capability of a startup lies in its workers rather than in its physical assets or processes implies that these new economy firms cannot be valued in the same way as old economy firms. What distinguished workers from physical assets is their ability to learn and expand their capabilities. In the fast moving world of high technology, it is not current skills that matter, but the ability to change as circumstances dictate. That flexibility is the essence of a real option and recognizing that fact is another key towards understanding the dynamics of the new economy.

Recall that the value of a real [call] option is decreasing in the exercise price and increasing in its variance and asset price. ${ }^{30}$ The former corresponds to the cost of the investment needed to purchase the asset in a good state, and as we have argued, this cost is relatively low in the new economy. The variability of the option corresponds to the capability of the startup to rapidly alter its plans as circumstances change, and that is a feature of the new economy, because the source of value is flexible people, unlike in the old economy with its reliance on less flexible processes and physical assets. Real options have far greater value than the net present value of a stable set of cash flows, which goes some way towards explaining the very high valuation of startups that have little other than a team of workers. This is not a case of market failure or "irrational exuberance", but rather a valid recognition of from where value is derived in the new economy.

The option theory also helps explain why, at the height of the boom, entrepreneurs were able to raise large sums of venture capital money without an iron clad business plan, or sometimes, with only the expectation that a business plan will follow subsequently (funding at the "cocktail napkin" stage). When a VC perceives a real option element to the team, the initial business idea that brings the team together is less important than what it can do once assembled. The team's option value remains even if the initial business plan fails and so venture capitalists gain from keeping the startup going to see what else develops. There are fewer physical resources on hand that constrain what the startup can do next and there are lower barriers in the new economy to translating that potential value into practice. It is also not surprising

\footnotetext{
${ }^{29}$ See also Leifer et al (2000), O'Reilly and Pfeffer (2000) and Hamel (2000) for further discussion of how management and personnel practices have to change in the new economy.

${ }^{30}$ Dixit and Pindyck (1995), Edleson (1999).
} 
then, that post-investment, investors give startups in the new economy a great deal of leeway to alter their original business plan, sometimes beyond recognition, when it proves inadequate, rather than liquidating the company and moving on. On the face of it, such behavior does not make sense. After all, the money already invested is a sunk cost, so logically the new business plan should be on an equal footing with all other opportunities. But once the option value of the workers in place is recognized, it makes sense to stick with the team at hand, since it is the very ability to change plans that is of value in the first place. ${ }^{31}$

However, there is also a price to be paid for a valuation model based on real options: far greater volatility as underlying assumptions change. Unlike for a traditional firm valued using stable discounted cash flows, valuations of new economy firms are based less on extrapolations of current results and more on expectations of what market spaces the firm's creative innovation will be able to open up and how much that space is likely to be worth. ${ }^{32}$ In other words, the valuation is based on the market's beliefs as to the ability of the managers of the firm to successfully create an innovation and translate it into profits. The fact that in the new economy the market is willing to base its valuation on the basis of the real option element of the firm's talent means that a startup can raise more cash at an earlier stage. But the flip side of that opportunity is that options are a far less solid basis of valuation than current cash flows, and if the market's faith in the firm wavers then the reduction in value is rapid and dramatic. The same forces apply to established firms that attempt to enter the new economy through creative innovation. They will find that their stock prices also become more volatile than they used to be, as the market shifts their basis of valuing the firm from cash flows to the opportunity cost of its innovations and its human resources.

Real option based valuation is then a two-edged sword that provides new economy firms with both great opportunities and great perils. Both outcomes are exacerbated when the market is driven by a herd mentality rather than a systematic case-by-case assessment of the business plans of each individual firm. Rather than dismissing the current market volatility as a sign of market failure, though, new economy managers must recognize that it is simply a reflection of fundamental changes in the way business are run, and so, of how they are valued.

\footnotetext{
31 "On the Internet, companies have to be ready to change goals or strategies virtually overnightÉ Some companies are writing and rewriting their strategies every quarter, or even every week-or else. 'It used to be that the big ate the small', says Geoff Yang, a partner in the Menlo Park, Calif. Venture-capital firm IVP/ Redpoint Ventures. 'Now the fast eat the slow."” BusinessWeek (November 1', 1999, page EB 52).
}

${ }^{32}$ Moore (2000, Chapter 2). 


\subsection{Retaining and Rewarding Workers}

One of the prominent characteristics of this new economy is the inability of many firms to keep the workers who generate creative innovations from leaving to market them on their own. There has been a great deal of discussion about how established firms can develop a more entrepreneur friendly climate internally. Hamel (1999) argues, for instance, that firms need to "Bring Silicon Valley Inside". But the fact remains that at even the most successful companies, the best employees still dream of the day when they can leave and do a startup of their own.

Workers have developed a keen awareness of the opportunity cost of their time. There was a time when leaving an established company to join a startup was considered a risky course of action. Even with the current recession, however, there is little doubt that there has been cultural shift in the attitudes of young employees, who feel that it is not leaving and so not "getting in on the action" that is considered the ultimate risk. In other words, their opportunity cost is perceived to be greater from staying than from going, and that attitude will undoubtedly reassert itself once the job market recovers. Adding to that incentive is the fact that the market seems to reward workers who have demonstrated the initiative to attempt a more entrepreneurial career if they wish to ever go back to an established firm. And why is that? Because someone who has self-selected to be part of an entrepreneurial effort is seen as more likely to be able to contribute towards the development of creative innovation.

Losing a reputation for creative innovation creates a downward spiral for attracting and retaining talented staff. Indeed, supportive technology positions are increasingly staffed only by workers who cannot leave for startups, such as those with limited immigration status or workers with weaker resumes. ${ }^{33}$ Why do creative workers go to startups rather than remaining with larger employers? The trite answer is that workers feel that it is a way of obtaining far greater wealth than they could if they remained with a larger, more established firm. We have already discussed why startups are able to obtain such high valuations from investors - the recognition of their option value. The real issue then, is why existing firms are unable to match the incentives provided by startups. One hypothesis is that they have no reason to do so: that the startups are pursuing new ventures unrelated and of no interest to the established firm. However, that explanation is contradicted by the frequent acquisition of startups by established firms. It is also far more likely that experienced workers will more readily perceive opportunities

\footnotetext{
33 "The Streets Are Paved With PC's: Wall Street and Silicon Alley Lure a New Breed of High-Tech Immigrants." The New York Times (August 16, 1998).
} 
in their own industry and be in a better position to develop creative innovations in their personal area of expertise, than outside it. The fact that the acquiring firm pays the high market valuation of the startup also suggests that the problem is not one of an inability to afford to match the rewards that startups offer workers.

We argue that the reason why firms are unable to retain the workers who are the source of critical creative innovations is because their managers have failed to recognize the defining forces of the new economy: the option value of workers, the shift from processes to people and indeed, the importance of creative innovation in the first place. Hamel (1999, page 77) offers the following anecdote: "Two years ago, the CEO of one of America's large information technology companies approached me with a simple question: 'What will it take for my company to capture a bigger chunk of Internet-related opportunities?' 'For starters, 'I replied, 'a willingness to create a slew of 30-year-old millionaires.' The CEO furrowed his brow and said, 'I can't see us doing that.' Not surprisingly, his company has missed the Internet bonanza." It is quite apparent that most firms have not been willing to pay their talented workers what the workers think that they can get from leaving and joining a startup. Our model suggests an explanation for why.

It is not surprising that old economy managers find it difficult to "create a slew of millionaires" amongst their employees because in the old economy few employees were that valuable. When implementing a strategy based on exploitive innovation, the key sources of value are the processes that translate incremental and systematic improvements in well-known technologies and methodologies into cost effective products. Exploitive innovation has to be achieved in a predictably reliable and scheduled fashion since its purpose is to upgrade existing product lines. Hence, the process of exploitive innovation is one of those that have to be made independent of the particular employees working on it at any given time. Firms cannot afford the risk of having expected improvements to their product lines held hostage to any particular worker's contribution. This is very much an environment in which process and assets in place - that includes, first and foremost, the very valuable asset of the existing product space-takes precedence over the contribution of any one worker.

A firm's Human Resources system would not be a well-designed strategic control system if it did not reflect this reality. When processes are the critical component for firm success, the worth of workers will be judged relative to the fact that they are only one input into a broader production function that also includes the firm's physical assets and processes. The main sources of value are the firm's processes and assets and so workers cannot expect to receive the bulk of the returns resulting from their use of them. HR's goal is to hire the right person to work with the firm's established processes and make effective use of its' assets. 
While the extent of a worker's contribution is obviously a function of their ability, ultimately it is the contribution, not the ability, which is rewarded.

This approach to evaluating and rewarding workers is logical and appropriate for performance evaluation in most large firms. But what this process is not designed to do is to evaluate the worth of an employee who is contemplating leaving to develop a creative innovation of his or her own, even when that idea is of obvious value to the firm and related to its product strategy. The fact that in the new economy the worker is no longer an interchangeable input into the production function but is rather a unique free agent with an option value is difficult to reconcile with the standard performance evaluation mentality.

The key point is that in the old economy most ideas could not be exploited outside an established company. Even if the innovation was creative rather than exploitive, the costs of developing the idea were so large as to preclude most startups from becoming a credible competitor, especially at a time when there was far less opportunity to practice outsourcing. Exploitive innovation is generic and needs the resources of a large firm to be marketable. It is inevitable that a perspective that an employee is but one input in a set of assets and processes, all of which are necessary for success, will affect the way in which the firm perceives its workers and assesses how they should be rewarded for their innovative ideas. It becomes difficult for human resource processes to give due weight to an idea itself, relative to the role that the firm's processes and assets will play in its exploitation, or for that matter, the role that they played in its development in the first place.

The dominant theory underlying human resource management and incentive pay, the principal/agent model, perpetuates this process-oriented perspective. It states that the level of incentive pay is a function of the worker's marginal productivity when using the firm's physical resources and process. The worker's own potential value independent of the firm only appears through the worker's "reservation wage". The presumption is that the alternative to working with this company is working in an equivalent job in a comparable company. ${ }^{34}$ There is no recognition that the alternative might be being an entrepreneur in a startup. In that case the alternative valuation of workers is not based on how much they can contribute as part of a similar production process, but on how successful they are likely to be when developing the creative innovation on their own. Since the costs of developing a creative innovation in the new economy are lower than that of an

\footnotetext{
${ }^{34}$ See Lambert (2001) for a survey of the principal/agent literature. Oyer (2000) is one of the very few papers that have paid attention to what the "reservation wage" actually represents, rather than simply taking it as an exogenous parameter. A more typical definition of a reservation wage is that it is the agent's "next-best opportunity [from] taking employment with someone else." Baron and Kreps (1999, page 566, emphasis added).
} 
exploitive innovation in the old, the opportunity cost of the worker is severely underestimated as a result of not recognizing the option component of the worker's entrepreneurial prospects. In the new economy it is precisely their option value that workers wish to be rewarded for, in recognition of the fact that their ideas are the real drivers of value.

Even when managers of old economy firms become aware that the rules have changed, psychologically and culturally it is difficult to give workers rewards commensurate with their option value. In particular, old economy firms face issues of internal equity of pay, a constraint not faced in a startup. Even if management is willing to reward a worker for his or her option value and not just as input into a broad production process, fellow employees may perceive that as favoritism or be subject to envy if they are not as innovative or flexible. More to the point, both managers and other workers are familiar with an exploitive innovation environment in which workers are interchangeable and so have roughly equal worth. Pay equity is a natural consequence of this setting and it is hard to overcome this belief and expectation that no one worker should be paid all that more than another.

In contrast to established firms, the startup market is keenly aware of the forces shaping the new economy. What an outsider, such as a venture capitalist, can do more easily than the firm, is to divorce the idea from the process and give due recognition to the human capital that underlies it. By contrast, the firm is always looking through the lens of the role that the assets and processes of the firm will play in transformation of the idea into value.

\subsection{Management Control in the New Economy}

The radical and fascinatingly novel business model that underlies the new economy firm has implications for all aspects of a firm's operations. While many have talked about the new strategies emerging in the new economy, far fewer have focused on whether the day to day tools of management—budgets, pay for performance, discounted cash flow-in use for the last half century retain their relevance. But it is worth remembering that all these management techniques developed at a time when the basis of value creation was physical assets. For example, the primary rationale for accounting is the safeguarding of the firm's property and all the tools that it has developed, from budgeting to activity based costing, are designed to serve that purpose. ${ }^{35}$ Most critical of all, labor had to be

\footnotetext{
35 "Accounting Controls are defined as the plan of the organization and all methods and procedures that are concerned with the safeguarding of assets and the reliability of financial records." Roehl-Anderson and Bragg (2000, page 12); "Cost accounting measures and reports financial and other information related to the acquisition or consumption of an organization's resources.” Horngren, Foster and Datar (2000, page 18).
} 
tightly controlled, being seen as a source of undesirable variation at best, and of slacking, theft and sabotage at worst.

The downturn has led many to now call for new economy firms to adopt traditional control systems as a way of achieving profitability faster and keeping burn rates under control. While there is an undoubted need for greater efficiency, the reliance on these old standbys of management control demonstrate that despite the talk about "putting people first" many managers fail to understand the different business model underlying the new economy. Their emphasis on people is really a reaction to the tight labor market and not because they recognize that people and not assets are the new sources of value creation in firms. If they did, they would see that all aspects of management have to be altered to reflect that paradigm shift. Clearly compensation is the first area that has to be looked at. But there is also need to increased the use of real option technology in capital budgeting as well as to revise assumptions about budgeting, control, empowerment and performance evaluation to reflect the shift from assets to people. For example, it is encouraging that many firms are now adopting Balanced Scorecards that give some weight to worker learning and development, along with traditional financial metrics. ${ }^{36}$

A novel management tool just coming into use in Silicon Valley is something whose rationale could have been predicted from the opportunity economy business model. That is the "spin-in" in which a firm in effect acts as a VC to its own employees. Rather than risk them leaving to form their own startup, a firm allows a group of employees to form and develop their innovation in-house. The firm promises to pay them essentially what they could have got if they carried out a successful IPO, but it retains the exclusive rights to the innovation. ${ }^{37}$ This is a very expensive procedure for a firm and raises serious issues of pay equity, even in a Silicon Valley firm. But firms such as Cisco feel that they have no choice but to adopt such novel management tools in response to the reality of an economy where it is worker talent that drives firm success, and not the assets and resources of the firm itself. Cisco spin-ins now generates most of their revenue and potential for growth, but they have also caused resentment amongst employees not chosen to participate in a spin-in.

The spin-in is only one example of the new tools that managers will have to come up with as they start to fully appreciate the new business model that underlies the new economy. It is not sufficient to pay lip service to the notion of a people based firm. Despite all the talk, few firms paid any greater regard for their

\footnotetext{
${ }^{36}$ Kaplan and Norton (1996).

${ }^{37}$ This discussion based on private communication between Cisco executives and the authors. The full details of how spin-in are structured at Cisco are confidential.
} 
employees in the first new economy recession than they did in the last, old economy one. The rationale for a layoff, after all, is that it is the firm's capital that must be safeguarded for a future recovery, as the ultimate source of profits, while workers are interchangeable and a variable cost that can be adjusted at will. Until firms start "laying off" assets instead, it cannot be said that they have truly recognized and internalized what it means to have the source of value creation shift from asset and processes to people.

\section{ECONOMIES OF SKILLS}

The new economy was not just a set of brash young firms with cool technology. It was more than a happy confluence of entrepreneurs and "irrationally exuberant" investors. It was and remains a comprehensive, consistent, integrated, selfreinforcing and self-perpetuating revolution in the very essence of what it means to be a business - of why firms exist, how they are run and what it takes for them to succeed. At its base is technological change, but what that technology looks like is less important than what it makes possible: a fundamental democratization of business, allowing startups to compete on level terms with the largest and most established firms. Not just technology is responsible for this, but also the ability to outsource virtually all business processes and so quickly achieve credibility and scale.

The effect of these two forces is to shift the strategy space from the exploitation of existing products to the development of creative new innovations. As a consequence, there is a correspondingly fundamental shift in the basis of value creation in firms, from processes and physical assets to human resources-to smart people. And when the flexibility that innovative people posses becomes the driving force in the economy, new ways of measuring their contribution must be used that recognizes their inherent option value. In this environment what you can do is more important than what you have done, your potential more valuable than your assets: in short, an economy keenly aware of its opportunity cost.

Commenting on the popularity of Applications Service Providers, Mr. Kneko Burney of Cahners In-Stat states that "Today, it's not about economies of scale but about economies of skill." ${ }^{38}$ In its recognition of the fundamental need in the New Economy to leverage the value creating capacity of human resources, this description is even more general than its author may realize. It is the very essence of the Opportunity Economy.

\footnotetext{
${ }^{38}$ New York Times (May 22 ${ }^{\text {nd }}, 2000$ ).
} 


\section{REFERENCES}

Alles, M., (2001): “A Critical Analysis of the“"Innovator's Dilemma”: Why Should New Technologies Cause Great Firms to Fail?” Unpublished working paper, Rutgers Business School.

Austin, R. D., Nolan, R. L., and Cotteleer, M., (2001): “Cisco Systems, Inc.: Implementing ERP”, Harvard Business School Teaching Note, n.5-699-031.

Baron, J. N., and Kreps, D. M., (1999): Strategic Human Resources: Frameworks for General Managers, Wiley.

Benson, J., (1999): “Outsourcing, Organizational Performance and Employee Commitment”, Economic \& Labor Relations Review, Vol. 10, n.1:1-21.

Bunnell, D., (2000): Making the Cisco Connection: The Story Behind the Real Internet Superpower, Wiley.

Christensen, C., (1997): The Innovator's Dilemma: When New Technologies Cause Great Firms to Fail, Harvard Business School Press.

Christensen, C., and Overdorf, M., (2000): "Meeting the Challenge of Disruptive Change", Harvard Business Review, March-April:66-76.

Cross, J., (1995): “British Petroleum's Competitive Approach”, Harvard Business Review, May-June:94-103.

Dixit, A. K., and Pindyck, R. S., (1995): ̈“"The Options Approach to Capital Investment", Harvard Business Review, May-June:105-118.

Edleson, M. E., (1999): "Real Options: Valuing Managerial Flexibility", Harvard Business School Teaching Note, n.9-294-109.

Ghemawat, P., and Baird, B., (2000): "Leadership Online: Barnes \& Noble vs. Amazon.com", Harvard Business School Teaching Note, n.5-798-119.

Gordon, R. J., (2000): "Does the "New Economy" Measure Up to the Great Inventions of the Past?" Journal of Economic Perspectives, Vol. 14, n.4:49-74.

Hamel, G., (1999): "Bringing Silicon Valley Inside”, Harvard Business Review, September-October:71-84.

Hamel, G., (2000): Leading the Revolution, Harvard Business School Press. 
Hansen, M., Nohria, N., and Tierney, T., (1999): "What's Your Strategy for Managing Knowledge?" Harvard Business Review, March-April:106-116.

Hemp, P., (2001): "Managing for the Next Big Thing: EMC's Michael Ruettgers", Harvard Business Review, January:130-141.

Horngren, C., Foster, G., and Datar, S., (2000): Cost Accounting: A Managerial Emphasis, Tenth Edition, Prentice Hall.

Kaplan, R., and Norton, D., (1996): Translating Strategy Into Action: The Balanced Scorecard, Harvard Business School Press.

Lacity, M. C., Willcocks, L. P., and Feeny, D. F., (1995): "IT Outsourcing: Maximize Flexibility and Control", Harvard Business Review, May-June:84-93.

Lambert, R., (2001): “Contracting Theory and Accounting", Journal of Accounting and Economics, Vol. 32, n.1:3-87.

Leifer, R., McDermott, C. M., O’Connor, G. C., Peters, L. S., Rice, M., and Veryzer, R. W., (2000): Radical Innovation: How Mature Companies Can Outsmart Upstarts, Harvard Business School Press.

Lewis, M., (1999): The New, New Thing: A Silicon Valley Story, Norton.

MacCormack, A., Verganti, R., and Iansiti, M., (2001): "Developing Products on "Internet Time": The Anatomy of a Flexible Development Process", Management Science, Vol. 47, n.1:133-150.

Moore, J. F., (1993): "Predators and Prey: A New Ecology of Competition", Harvard Business Review, May-June:75-86.

Moore, M., (2000): Living on the Fault LineüHarper Business.

O'Reilly, C. A., and Pfeffer, J., (2000): Hidden Value: How Great Companies Achieve Extraordinary Results with Ordinary People, Harvard Business School Press.

Oyer, P., (2000): "Why Do Firms Use Incentives that have No Incentive Effect?" Unpublished working paper, Stanford Business School.

Porter, M., (1996): "What is Strategy?" Harvard Business Review, NovemberDecember:61-78.

Porter, M. (2001): "Strategy and the Internet", Harvard Business Review, March:62-79. 
Prahalad, C. K., and Hamel, G. (1990): “The Core Competence of the Corporation", Harvard Business Review, May-June:79-90.

Roberts, M. J., and Tempest, N. (1999): "Randy Komisar: Virtual CEO”, Harvard Business School Case, n.9-898-078.

Roehl-Anderson, J. M., and Bragg, S. M. (2000): The Controller's Function: The Work of the Managerial Accounting, Second Edition, Wiley.

Sahlman, W. (1999): "The New Economy is Stronger Than You Think", Harvard Business Review, November-December:99-107.

Shane, S. (2001): "Technological Opportunities and New Firm Creation", Management Science, Vol. 47, n.2:205-220.

Shiller, R. J. (2000):Irrational Exuberance, Princeton University Press.

Suarez-Villa, L. (1998): "The Structures of Cooperation: Downscaling, Outsourcing and the Networked Alliance", Small Business Economics, Vol. 10, n.1:5-16.

Tapscott, D., Ticoll, D., and Lowy, A. (2000): Digital Capital: Harnessing the Power of Business Webs, Harvard Business School Press.

Upton, D. (1995): “What Really Makes Factories Flexible?", Harvard Business Review, July-August:74-86.

Wheelwright, S. C., Holloway, C. A., Kasper, C. G., and Tempest, N. (2001): "Cisco Systems, Inc.: Acquisition Integration for Manufacturing", Harvard Business School Teaching Note, n.5-600-134.

Vasarhelyi, M. (2000): "Internet Ecology", paper presented at the Rutgers University New Economy Conference.

Young, S., and Macneil, J. (2000): "When Performance Fails to Meet Expectations: Managers' Objectives for Outsourcing”, Economic \& Labor Relations Review, Vol.11, n.1:136-68. 